\title{
COMMENT
}

\section{Global sports governance and corruption}

\author{
John Forster ${ }^{1}$
}

\begin{abstract}
This article examines Global Sports Organisations (GSOs) in the light of the recent and numerous allegations and findings of corruption against them. In a seemingly unprecedented step in World sport, FIFA, the global governing body of football (or soccer), has banned its own president (Sepp Blatter) from any activity in the sport for 8 years for not fulfilling his fiduciary duties to the organization. It suggests why this corruption exists and persists, and in this light, it also suggests what form remedies must take. In briefly describing the genesis of the GSOs, it is argued that the roots of the corruption go back to the structures put in place in the early days of the GSOs, most notably a lack of transparency, even though they were not then necessarily corrupt. The current power of the GSOs is then briefly described, and a new argument is made, namely that the GSOs, with few exceptions, have either monopoly or quasi-monopoly status that aggravates the tendency to corruption. Such monopolistic status can be maintained even when it is known or suspected that a GSO is corrupt. This article is published as part of a thematic collection dedicated to global governance.
\end{abstract}

\footnotetext{
${ }_{1}^{1}$ Accounting, Finance and Economics, Griffith University, Brisbane, Australia Correspondence: (email: j.forster@griffith.edu.au)
} 


\section{Introduction}

- he Global Sports Organisations (GSOs) are the world governing bodies of sports and associated activities (Forster, 2006). They are a large part of global civil society but are often overlooked by those interested in global governance and global civil society. As with many non-government governance bodies they are non-profit organizations, but they differ in that they have enormous abilities to generate income via global sporting events. This arose as sport became global mass entertainment, first through radio. But after World-War II the advent of TV allowed transmitted sport to become visual, dramatically increasing its revenue potential (Forster and Pope, 2004; Evens et al., 2013). Colour TV further intensified this. It is the GSOs' invention, ownership and control of global sports events such as World Championships and the Olympic Games, which means these revenues accrue directly to the GSOs. In turn these revenues are the incentive for corruption within the GSOs.

The original governance function of the GSOs was to set the framework and policies that allow sport to operate at a global level, as opposed to being involved in day-to-day operational and financial issues. This remains the case, but this line is necessarily blurred when they own, run and promote peak global events such as World Championships. The GSOs also claim, as part of their governance function, to promote a sporting ethos among sports participants, especially the athletes. Thus they protect the integrity of sport by prevention of various forms of cheating by athletes. Most notably this takes the form of doping in various forms. Unfortunately this differs from the reality, as in The International Cycling Union's knowing inaction over doping long before and during the Lance Armstrong revelations (Mignon, 2003; Davidson, 2015).

All GSOs proclaim lofty ideals of governance. FIFA's (the global governing body of football, or soccer) Website states, "As football's world governing body, FIFA is firmly committed to the principles of good governance, transparency and zero tolerance towards any wrongdoing-whether it is in sporting contests or any other context of association football. FIFA has adapted its structures and procedures in order to meet the evolving needs of the game's governance and respond to the increasing complexity of its functions and operations" (http://www.fifa.com/about-fifa/who-we-are/index. $\mathrm{html}$ ). Yet FIFA is prominent among those major GSOs where corruption has been exposed, as it has among others, such as in the IOC (Olympics), IAAF (athletics) and the ICC (cricket).

\section{The creation of the GSOs}

The nineteenth century was a revolutionary period in sport. Sport went from being localized, amateur, culturally peripheral and ungoverned to being organized, commercial, global and governed. These changes culminated in the founding of the first GSOs-as non-profit-making bodies. Other organizational innovations appeared. These included the first sports leagues being founded in the United States and then in soccer in the United Kingdom. Even before this "rules of the game" were being decided on, written down, administered, popularized and enforced by sanctions through national or quasi-national bodies operating as governance bodies. Purpose-created bodies appeared such as the FA (The Football Association, founded in 1863) in England. Sometimes dominant clubs, especially in Britain, took on the governance role, such as St Andrews (founded in 1754) in golf and the MCC (founded in 1787) in cricket. These two clubs ultimately became de facto World ruling bodies, although the first purpose-founded GSO seems to have been FIG (International Gymnastics Federation). FIG was originally Europe-centred rather than global. The Belgian Nicholas Cupérus invited the French Gymnastics Society, the Dutch Gymnastics Union and the two Belgian federations of Wallonia and Flanders to come together, but importantly to retain their separate identities. Interestingly, this new organization's objectives included exclusion of religious and political objectives, exclusion of professional athletes and the organization of an international competition (this last Cupérus opposed). Nothing was said of the new organization being a governing body but, in effect, this became effective with the first Gymnastics World Championships held in 1903. The predecessor of the present International Rugby Board (IRB) was formed in 1883. The International Amateur Athletic Federation (IAAF), predecessor of the International Association of Athletics Federations (also IAAF) was created in 1912, specifically as their international governing authority.

The more successful each new international organization became the more national federations joined, making them more and more global. This was also important in facilitating corruption, as each new national organization that joined the GSO not only diluted the strength of the national bodies against the GSO, but also made it difficult for opposing global bodies to arise. This became the standard pattern of GSO development through the twentieth century. The inter-war years (1918-1939) saw new GSOs appear, mostly from within Europe. Most international sport activities then halted during the Second World War, as they had during the First World War. The new GSOs were often for minor, much less commercial sports such as archery, fencing and recreational activities such as mountaineering, with fewer opportunities for corruption. GSOs grew in number and in size, evolving over the twentieth century and into the twenty-first century as the governing bodies of: (1) sports; (2) sporting events; and (3) sport-related specialist activities such as sports medicine and doping. Their immense cultural and economic power grew as governments became anxious to host global events-World Championships and notably the Olympic Games.

Some specialist GSOs are now particularly important in sports governance. They include two of the most significant and powerful GSOs. These are WADA (World Anti-Doping Authority) and CAS (Court of Arbitration for Sport), both evolving from the Olympics movement at the end of the twentieth century. WADA is well known and its function self-stated. Less well known is CAS. In theory it is an independent institution, and is involved in resolving legal and other disputes in sport. Thus Sepp Blatter has stated that he will appeal his 8 year ban (FIFA, 2015) from soccer activity by FIFA to CAS (BBC, 2015b). While CAS's decisions have no legal standing in the legal system of any country, if a "case" has been heard in CAS and a party to the dispute wishes to pursue it further within a national legal system, those courts will often refuse a hearing, arguing that the dispute has been reasonably dealt with in CAS (unless a matter of legal principle or human rights is involved). In this context Sugden and Tomlinson (1998) correctly note the importance of Article 58 of FIFA's statutes, which states "National associations, clubs or club members shall not be permitted to refer disputes with the federation or other associations, clubs or club members to a court of law and they shall agree to submit each one of such disputes to an arbitration tribunal appointed by common consent". (Article 58/1, quoted in Sugden and Tomlinson, 1998: 49). This has been a common approach among GSOs, arguably limiting legal rights, and now strengthened by the existence of CAS. This can be interpreted as the GSOs seeing themselves as having almost trans-national quasi-legal jurisdiction that limits access to the law courts and legal rights of bodies and individuals in their national jurisdictions.

\section{The power and networks of the GSOs}

Some individual GSOs have enormous specific political influence, with governments courting them in order to stage global events 
such as the Olympic Games and soccer's World Cup. This courtship is not surprising if the recent WADA (World AntiDoping Authority) (2015) independent report is correctcommercial and national prestige imperatives can subvert even those nationally supported systems that are designed to uncover wrongdoing in sport. They are significant enough to make global news (BBC, 2015a). This was the case for East Germany in the past and is apparently the case for Russia in the present, with the IAAF Council provisionally suspending the Russian athletics federation from all IAAF-recognized competition including the Olympics (IAAF, 2015). "There were specific recommendations for WADA to declare the WADA-accredited Moscow Laboratory and Russian National Anti-Doping Agency (RUSADA) noncompliant. There was also a recommendation for the All-Russian Athletics Federation (ARAF) to be declared non-compliant, which WADA will refer to the International Association of Athletics Federations (IAAF) so that appropriate action can be taken against ARAF as one of its member federations". This was using "powers under the IAAF Constitution Article 6.11(b) and Article 14.7 the members of the IAAF Council provisionally suspended ARAF on charges of breach of the Objects of the IAAF" (IAAF, 2015). This is a clear struggle for good governance to assert itself. Well over a decade ago Millet et al. (1999) noted the GSOs as "immensely powerful civil associations of cultural elites from across the world that frequently dictate terms to governments and business through a complex relationship of interdependency with nationalism and corporate funding" (496-497). This is what Numerato and Baglioni (2012) have called in the context of sport governance, "the dark side of social capital", although they were examining the national rather than global levels of governance. Illustrating this interdependency at the individual level, the acting president of FIFA Issa Hayatou has not only been a FIFA vice-president since 1992, but was apparently unaware of the corruption around him. He is acting president as the president (Sepp Blatter) is suspended while under investigation for financial irregularities by the Swiss police among others. Hayatou is also an IOC member (since 2001). These interdependencies operate very much at the personal level, as well as in terms of the official relationship between these organizations. These organizational and personal interdependencies are especially strong with many being both headquartered and legally domiciled in Switzerland. There the authorities have seemingly tacitly supported a lack of transparency among these organizations (see Forster and Pope, 2004; Forster, 2006; Transparency International, 2015). Henne (2015) argues very strongly for transparency.

The IOC has had many accusations of corruption. These came to a head with the Salt Lake City bid for the 2002 Winter Olympics. The then president of the IOC, Juan Antonio Samaranch blamed individuals rather than any systemic fault in the organization, saying: "My apology is for the actions of those IOC members who violated the bidding process for the 2002 Winter Games". At the same time he argued that those members recommended for expulsion-six IOC members were eventually expelled-had not broken "any laws" (Bowser, 1999). Accusations of corruption also attended the FIFA presidential election of 2002 (Darby, 2003). The IRB has been followed by such accusations, as have various elements of the administration of cricket (Rae, 2001). In professional boxing corruption is legendary, the governance function, especially the sanctioning of world title fights, becoming a commercial endeavour rather than a neutral regulatory activity. This has helped create numbers of professional boxing boards and organizations, especially in the United States, each claiming a global governance role on slender grounds (Forster and Pope, 2004).

However, sports law is concerned more with the governance of athletes than with the organizations themselves. CAS does not cover such practices but is concerned with the governance of athletes. Partly this is unavoidable as corrupt financial practice is a matter for criminal or corporate law. It examines athletes and hears their appeals. These are often against other athletes, competition judges or exclusion from competition for performance-enhancing drug offences. However, it has been found against GSOs in their dealings with individual athletes, as in the case of Oscar Pistorius against the IAAF (CAS, 2008). In addition, sports body corruption is often political rather than directly financial. Thus the president of a GSO can use financial patronage to poorer national associations to secure votes in presidential elections. This can then be used not only to secure power but like patronage to hide financial corruption through patronage. Some have questioned the impartiality of CAS, because of its association with the IOC. This has been explicitly rejected by the legal system of Switzerland where CAS is domiciled and headquartered.

In essence the increasingly recognized levels of corruption within the GSOs implies that a systematic approach to global sport governance is overdue. There is no coherent literature on the subject.

\section{GSOs and governance monopolies}

Why is corruption occurring across several different GSOs? They have several commonalities, including the already mentioned large revenues, which are exacerbated by the fact that they do not rely on their members' contributions, but many member nations rely on their disbursements, creating a clientele and the potential for patronage at both national and individual levels. Magnifying this, however, is the argument that for a governance organization to be effective it has to have either a monopoly or very close to a monoply of that governance role. It has already been pointed out that GSO statutes are designed to reinforce this monopoly control by restricting access to alternative governance mechanisms (that is, the law courts). By design or by accident CAS helps reinforce this for the GSOs as a whole. This implies not only governance but control, and this helps exploitation of the governed.

Yet the GSOs have no incontravertible mandate to be the governing bodies over the sports and sports activities they cover. In principle there is no reason why other organizations cannot arise and wrest away control and hence the governance function. In practical terms, of course, this is currently inconceivable even for, say, FIFA despite its current troubles. But while FIFA is indisputably the GSO of football, other GSOs have areas of interest and governance activities that overlap and to a degree compete with other GSOs. In professional boxing there are notoriously the WBA, IBF, WBO and WBC and probably others, all claiming heavyweight championships of the World. In competitive climbing there exists both the UIAA (International Climbing and Mountaineering Federation-Union International des Associations d'Alpinisme-http://www.theuiaa.org). In addition there is The International Federation of Sport Climbing founded in the late twentieth century-http://www.ifsc-climbing. org). The UIAA runs competitive Ice Climbing, while the IFSC governs several variants of competitive rock climbing, usually on artificial indoor climbing walls. They can therefore avoid harmful direct competition with each other in these areas, although neither can avoid the competitive aspect of maintaining revenue streams for the two GSOs. While their respective Websites show very clear differences of emphasis, there is no reason why the UIAA, being the older organization, if it had acted more quickly or with more foresight, could not have controlled the commercial areas now claimed by IFSA. In the fields of archery, martial arts, boxing and many other sports there are overlapping areas where governance is claimed. In addition there are several GSOs 
running World Championships in various sports, often overlapping with the Olympics (http://www.ioc.org) for control. Possibly the clearest example is the IAAF (International Association of Athletics Federations) that runs an Athletics World Championship. That alternative competition is undesirable for GSOs and their revenue streams in the area of their World Championships can be seen in the following statement: "Approximately 90 per cent of FIFA's revenue is generated through the sale of television, marketing, hospitality and licensing rights for the FIFA World Cup ${ }^{\text {tw }) ~(h t t p: / / w w w . f i f a . c o m / g o v e r n a n c e / f i n a n c e s / ~}$ index.html). A major factor in explaining why these governance monopolies remain despite their apparent contestability is that the political and economic entry costs are so high, and especially so for entry against the early mover GSOs (that is, those that established themselves before the twentieth century or at least the First World War). This allowed them to build traditions and assets such as ownership of the World Cup. This then explains why FIFA, the IOC and the IAAF, despite their records of internal corruption, are not easily discarded, by either sports associations or by sovereign nations. For a national sports association to leave its GSO is to face the sanction of being ostracized from international competition at every level.

\section{Conclusions}

It is now possible to suggest why systemic corruption appears in sports global governance organizations. Part of the answer lies in the enormous funds they generate, control and disburse. Furthermore, the GSOs have enormous strength compared with their constituent member associations. What has been argued here is the fact that monopolies through their governance functions allows much of this to occur. Patronage can reduce even further the voice of both constituent associations and individuals associated with the GSO. This intersects with the "dark side" of their linked existences, often through their Swiss domicile, which has helped deny transparency. Recent activity by the Swiss authorities in relation to FIFA may herald a change but, for the reasons given, it seems unlikely that GSO corruption will die soon. All of the evidence is that these global governance bodies do not govern themselves well, and little evidence suggests this will soon change.

\section{References}

BBC. (2015a) Doping \& corruption report a "dark day" for athletics, http://www. bbc.com/sport/athletics/34766733, accessed 10 November 2015.

BBC. (2015b) "FIFA: Sepp Blatter and Michel Platini get eight-year bans", http:// www.bbc.com/sport/0/football/35144652-21-12-2015.

Bowser B (1999) Too far for the gold, http://www.pbs.org/newshour/bb/sports/ jan-june99/olympics_1-25.html, accessed 25 January 1999.

CAS. (2008) Arbitration CAS 2008/A/1480 Pistorius v/ IAAF, award of 16 May 2008, Athletics Eligibility for an athlete with disabilities to compete in IAAF-sanctioned events alongside able-bodied athlete Standard of proof. No proven biochemical or metabolic advantage over other athletes due to the prosthesis, http://jurisprudence. tas-cas.org/sites/CaseLaw/Shared\%20Documents/1480.pdf.

Darby P (2003) Africa, the FIFA presidency, and the governance of world football: 1974, 1998 and 2002. Africa Today; 50 (1): 3-24.

Davidson K (2015) International Cycling Union shielded Lance Armstrong from positive drug tests, concludes report from Cycling Independent Reform Commission, http://www.smh.com.au/sport/cycling/international-cycling-unionshielded-lance-armstrong-from-positive-drug-tests-concludes-report-fromcycling-independent-reform-commission, accessed 10 November 2015.

Evens T, Iosifidis P and Smith P (2013) The Political Economy of Television Sports Rights. Palgrave Macmillan: London.

Forster J (2006) Global Sports Organisations and their governance. Corporate Governance: The International Journal of Business in Society; 6 (1): 72-83.

FIFA. (2015) Independent Ethics Committee bans Joseph S. Blatter and Michel Platini, http://www.fifa.com/governance/news $/ \mathrm{y}=2015 / \mathrm{m}=12 /$ news $=$ indepen dent-ethics-committee-bans-joseph-s-blatter-and-michel-platini-2747411.html, accessed 21 December 2015.

Forster J and Pope N (2004) The Political Economy of Global Sporting Organisations. Routledge: London.

Henne K (2015) Reforming global sport: Hybridity and the challenges of pursuing transparency. Law \& Policy; 37 (4): 324-349.

IAAF. (2015) IAAF provisionally suspends Russian Member Federation ARAF, Press Release Monaco, http://www.iaaf.org/news/press-release/iaaf-araf-sus pended, accessed 13 November 2015.

Mignon P (2003) The Tour de France and the doping issue. The International Journal of the History of Sport; 20 (2): 227-245.

Millet T, Lawrence G, McKay J and Rowe D (1999) Playing the world. Peace Review: A Transnational Quarterly; 11 (4): 495-499.

Numerato D and Baglioni S (2012) The dark side of social capital: An ethnography of sport governance. International Review for the Sociology of Sport; 47 (5): 594-611.

Rae P (2001) Bribery and corruption in the game of rugby union, http://www. rugby.com.au/, accessed 10 November 2015.

Sugden J and Tomlinson A (1998) FIFA and the Contest for World Football: Who Rules The People's Game? Polity Press: Cambridge, UK.

Transparency International. (2015) https://www.transparency.org/topic/detail/ sport/ https://www.transparency.org/news/pressrelease/football_associations_ publish_little_or_no_information_on_millions_of_dollars, received from FIFA, accessed 21 November 2015.

WADA (World Anti-Doping Authority). (2015) WADA welcomes independent commissions report into widespread doping in sport, https://www.wada-ama org/en/media/news/2015-11/wada-welcomes-independent-commissions-reportinto-widespread-doping-in-sport, accessed 15 November 2015.

\section{Additional information}

Competing interests: The authors declare no competing financial interests.

Reprints and permission information is available at http://www.palgrave-journals.com/ $\mathrm{pal} /$ authors/rights_and_permissions.html

How to cite this article: Forster J (2016) Global sports governance and corruption. Palgrave Communications. 2:15048 doi: 10.1057/palcomms.2015.48.

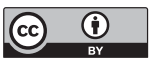

This work is licensed under a Creative Commons Attribution 4.0 International License. The images or other third party material in this article are included in the article's Creative Commons license, unless indicated otherwise in the credit line; if the material is not included under the Creative Commons license, users will need to obtain permission from the license holder to reproduce the material. To view a copy of this license, visit http://creativecommons.org/licenses/by/4.0/ 